\title{
First report on the validity of a continuous Metabolic Syndrome score as an indicator for Metabolic Syndrome in a national sample of paediatric population - the CASPIAN-III study
}

Pierwsze doniesienie na temat wyniku oceny trafności ciągłego wskaźnika zespołu metabolicznego jako wskaźnika obecności zespołu metabolicznego przeprowadzonej w ogólnokrajowej próbie reprezentatywnej populacji pediatrycznej — badanie CASPIAN-III

\author{
Gita Shafiee ${ }^{1,2}$, Roya Kelishadi ${ }^{3}$, Ramin Heshmat ${ }^{1,2}$, Mostafa Qorbani ${ }^{4,5}$, Mohammad Esmaeil Motlagh ${ }^{6,7}$, \\ Tahereh Aminaee', Gelayol Ardalan', Mahnaz Taslimi ${ }^{7}$, Parinaz Poursafa ${ }^{3}$, Bagher Larijani ${ }^{1}$
}

${ }^{1}$ Endocrinology and Metabolism Research Center, Endocrinology and Metabolism Clinical Sciences Institute,

Tehran University of Medical Sciences, Tehran, Iran

${ }^{2}$ Chronic Diseases Research Center, Endocrinology and Metabolism Population Sciences Institute, Tehran University of Medical Sciences, Tehran, Iran

${ }^{3}$ Department of Paediatrics, Child Growth and Development Research Centre, Isfahan University of Medical Sciences, Isfahan, Iran

${ }^{4}$ Department of Public Health, Alborz University of Medical Sciences, Karaj, Iran

${ }^{5}$ Department of Epidemiology, Iran University of Medical Sciences, Tehran, Iran

${ }^{6}$ Department of Paediatrics, Ahvaz Jundishapur University of Medical Sciences, Ahvaz, Iran

${ }^{7}$ Bureau of Population, Family and School Health, Ministry of Health and Medical Education, Tehran, Iran

${ }^{8}$ Bureau of Health and Fitness, Ministry of Education and Training, Tehran, Iran

\begin{abstract}
Introduction: The aim of this study was to assess the validity of a continuous Metabolic Syndrome score (cMetS) in a nationally representative sample of Iranian children and to identify sex and age-specific optimal cut-off points of cMetS that are associated with MetS. Material and methods: This study was conducted among 3,254 schoolchildren aged 10-18 years. cMetS was derived by aggregating age and sex-standardised residuals of waist circumference (WC), mean arterial pressure (MAP), glucose, high density lipoprotein-cholesterol (HDL-C) and triglycerides (TG). To determine the optimal cut-off points of cMetS for predicting MetS, receiver operator characteristic (ROC) curve analysis was used with an estimation of the variables' sensitivity and specificity.

Results: A graded relationship was documented between $c M e t S$ and the number of risk factors. Increasing mean values of cMetS with increasing numbers of components were apparent for both genders. The overall optimal cMetS cut-off point for predicting the presence of MetS was 2.93 [sensitivity $=92 \%$, specificity $=91 \%$, area of the curve $=0.96(0.95-0.97)]$. The values for boys and girls were 2.97 and 3.26 respectively in the total study. Conclusion: This nationwide study confirmed the validity of the cMetS score in a population-based sample of Iranian children. cMetS appears to be an appropriate index for investigating the association between potential risk factors and MetS in epidemiological research in Iran. (Endokrynol Pol 2013; 64 (4): 278-284)
\end{abstract}

Key words: continuous Metabolic Syndrome score, validity, children

\section{Streszczenie}

Wstęp: Celem pracy była ocena trafności ciągłego wskaźnika zespołu metabolicznego (cMetS) na próbie reprezentatywnej irańskich dzieci oraz zidentyfikowanie zależnych od płci i wieku optymalnych wartości odcięcia wskaźnika cMetS związanych z zespołem metabolicznym. Materiał i metody: Badanie zostało przeprowadzone z udziałem 3254 uczniów w wieku od 10 do 18 lat. cMetS był ustalany poprzez zagregowanie residuów standaryzowanych względem wieku i płci następujących parametrów: obwodu w pasie (WC, waist circumference), średniego ciśnienia tętniczego (MAP, mean arterial pressure), stężenia glukozy, stężenia cholesterolu frakcji lipoprotein wysokiej gęstości (HDL-C, high density lipoprotein cholesterol) oraz stężenia triglicerydów (TG). W celu ustalenia optymalnych punktów odcięcia dla przewidywania obecności zespołu metabolicznego na podstawie cMetS zastosowano analizę krzywej ROC (receiver operating characteristic) z oszacowaniem czułości i swoistości zmiennych.

Wyniki: Wykazano stopniowany związek między wskaźnikiem cMetS a liczbą czynników ryzyka. W przypadku obu płci zaobserwowano wyraźny wzrost średnich wartości wskaźnika cMetS wraz ze wzrostem liczby komponentów. Ogólna optymalna wartość odcięcia wskaźnika cMetS dla przewidywania obecności zespołu metabolicznego wyniosła 2,93 [czułość $=92 \%$, swoistość $=91 \%$, pole powierzchni pod krzywą $=0,96(0,95-0,97)]$. Wartość dla chłopców wyniosła w badaniu 2,97, a dla dziewcząt $-3,26$.

Wniosek: W przeprowadzonym badaniu ogólnokrajowym potwierdzono trafność wskaźnika cMetS w populacji irańskich dzieci. Wskaźnik cMetS wydaje się odpowiednim wskaźnikiem do zastosowania w badaniach epidemiologicznych nad związkiem pomiędzy potencjalnymi czynnikami ryzyka a występowaniem zespołu metabolicznego w Iranie. (Endokrynol Pol 2013; 64 (4): 278-284)

Słowa kluczowe: ciągły wskaźnik zespołu metabolicznego, trafność, dzieci

Ramin Heshmat M.D. Chronic Diseases Research Center, Endocrinology and Metabolism Population Sciences Institute, Tehran University of Medical Sciences, Tehran, Iran, No. 111, 19th St., North karegar, Tehran 14579-65597, Iran, e mail: rheshmat@tums.ac.ir 


\section{Introduction}

Metabolic Syndrome (MetS) is characterised by a cluster of risk factors that confers an increased risk for cardiovascular disease mortality and morbidity better than any of its individual components [1]. The prevalence of MetS is rising in the adult population worldwide [2]. A growing body of evidence has demonstrated that exposure to obesity in early life significantly contributes to the development of MetS during childhood and adolescence [3]. The lack of a universal definition of MetS in the paediatric age group may be the cause of controversial findings across epidemiologic studies and the low prevalence of MetS in some populations $[4,5]$. Because of the low prevalence rate, the American Diabetes Association and the European Association for the Study of Diabetes have recommended using a continuous value of MetS (cMetS) risk score for association studies between MetS and potential risk factors in children and adolescents [6].

Several studies have supported using a cMetS risk score instead of binary definition in epidemiologic studies $[7,8]$. Such a definition is proposed to have the following advantages: a) cardiovascular and diabetes risk is a progressive function and increases progressively as the number of MetS components increases, it also eliminates the need to dichotomise these components; b) statistical power decreases with dichotomising continuous outcome variables; and c) compared to the dichotomous approach, cMetS risk score is more sensitive and less error-prone [9-11]. Previous methods used to derive the $\mathrm{cMet} S$ score include principal components [12], Z scores [13-15], and percentile rankings [16]. Few studies have examined the construct validity of cMetS value and its association with MetS in children and adolescents [17, 18].

Middle East populations are suggested to bear the highest worldwide burden of diabetes up to 2020 [19]. Similar to most low- and middle-income countries, Iran is facing an epidemiological shift, most notably in terms of nutrition transition [20]. Thus, it is important to determine a valid score for the definition of paediatric MetS, and to identify at-risk individuals to help the primary prevention of underlying factors of MetS.

We aimed to determine the validity of cMetS, and to identify the age- and gender-specific optimal cut-off points of cMetS in a nationally representative sample of the paediatric population.

\section{Material and methods}

\section{Participants and study design}

The data used in this study was collected as part of the 'National Survey of School Student High Risk Behav- iours' (2009-2010) as the third survey of the school-based surveillance system entitled 'Childhood and Adolescence Surveillance and Prevention of Adult Noncommunicable Disease' (CASPIAN) study. We have previously described the methods of this study in detail [21]. The study was approved by the ethics committee and other relevant national regulatory organisations.

The present study was performed among 3,254 pupils aged 10-18 years who were selected via multistage random cluster sampling method from urban and rural areas of 27 provinces in Iran. Eligible schools for our study were stratified according to the information bank of the Ministry of Health and Medical Education and then they were selected randomly. In selected schools, the pupils were also selected randomly. Sampling and examinations were begun after complete explanation of the study's objectives and protocols for pupils and their parents, obtaining written informed consent from parents and oral assent from the pupils. A team of trained health care professionals recorded information in a checklist and carried out the examinations under the standard protocol using calibrated instruments.

\section{Clinical and laboratory measurements}

Height $(\mathrm{Ht})$ and weight $(\mathrm{Wt})$ were measured without shoes and with light clothing, and body mass index $\left(B M I=\right.$ weight $\left[\mathrm{kg} /\right.$ height $\left.\left[\mathrm{m}^{2}\right]\right)$ was calculated. Waist circumference (WC) was measured midway between the lower border of the rib margin and the iliac crest at the end of normal expiration. WC and height were measured using a non-elastic tape. Two measurements of systolic blood pressure (SBP) and diastolic blood pressure (DBP) were performed using a standardised mercury sphygmomanometer on the right arm after a 15-minute rest in a sitting position; the first and fifth Korotkoff sounds were recorded as systolic and diastolic BP, respectively. The mean of the two measurements was considered as the subject's blood pressure. Mean arterial pressure (MAP) was calculated using the following formula: $\mathrm{MAP}=$ $=[(\mathrm{SBP}-\mathrm{DBP}) / 3]+\mathrm{DBP}$.

A blood sample was drawn between 7 am and 9 am from all the study participants after 12 to 14 hours of overnight fasting and delivered to the laboratory on the same day. Fasting blood glucose (FBG), total cholesterol (TC), high density lipoprotein-cholesterol (HDL-C) and triglycerides (TG) were measured enzymatically by auto-analysers. HDL-C was determined after dextran sulphate-magnesium chloride precipitation of nonHDL-C [22]. Considering that collecting high quality data was critical to the success of our multi-centre project, the Data and Safety Monitoring Board (DSMB) of the project was taken in account the different levels of quality assurance and control. 


\section{Definition of terms}

\section{Metabolic Syndrome (MetS)}

Since no universally accepted definition exists for MetS in children and adolescents, as in the first survey of the CASPIAN study [5] we used the definition provided by Cook et al. [23]. This definition is based on criteria analogous to those of the National Cholesterol Education Programme Expert Panel on Detection, Evaluation, and Treatment of High Blood Cholesterol in Adults Adult Treatment Panel III (ATP III) [24]. It defines MetS as having at least three of the following criteria: WC at or above the 90th percentile value for age and sex; SBP and DBP at or above the 90th percentile for age, sex and height; the midpoint value for HDL-C $(\leq 40 \mathrm{mg} / \mathrm{dL})$ was used as a 10th percentile value; the midpoint value for TG $(\geq 110 \mathrm{mg} / \mathrm{dL})$ was taken as the 90 th percentile value for age. FBG levels of $\geq 100 \mathrm{mg} / \mathrm{dL}$ were considered to be high [25].

\section{Calculation of cMetS score}

The cMetS score was derived by first standardising the residuals for WC, MAP, HDL-C, TG, and FBG by regressing them on age and sex to account for age- and gender-related differences [8]. Because the standardised HDL-C is inversely related to the MetS risk, it was multiplied by -1 . The cMetS score was calculated as the sum of the standardised residuals ( $z$ scores) for the individual variables. These factors were the same variables used in adult clinical criteria for MetS [26]. MAP was used since including both SBP and DBP would load two BP variables in its calculation. A higher cMetS score indicates a less favourable metabolic profile.

\section{Statistical analysis}

Findings on continuous variables were expressed as means \pm standard deviation (SD) and categorical data was expressed as a percentage. The Student two-tailed $t$ test was applied to compare the mean differences of the variables between both gender and age.

To determine the optimal cut-off point of cMetS for predicting MetS, receiver operator characteristic (ROC) curve analysis was used with an estimation of the variable's sensitivity and specificity. The cut-off point for each variable was assessed by the minimum value of [27] which represents the maximum sum of sensitivity and specificity (MAXss) in each gender stratified by age.

The area under curve (AUC) relates to the overall ability of using the cMetS cut-off point to discriminate between those with and without MetS. In this analysis, AUC can be considered to be equal to the probability that a randomly drawn individual from a sample of subjects with MetS has a higher cMetS than a person randomly drawn from the non-MetS sample. AUC can be interpreted according to the following principles: test equal to chance (AUC $=0.5)$, less accurate $(0.5<$ AUC $\leq 0.7)$, moderately accurate $(0.7<$ AUC $\leq 0.9)$, highly accurate $(0.9<\mathrm{AUC} \leq 1.0)$, and perfect performance tests $(\mathrm{AUC}=1.0)$ [28].

SPSS software package (version 16; SPSS Inc., Chicago, IL, USA) was used for data analyses and a $p$ value of $<0.05$ was considered to indicate statistical significance.

\section{Results}

The participants in this multicentre study included 1,679 boys and 1,575 girls aged 10-18 years. The anthropometric and metabolic characteristics of the individuals who were eligible for this study are stratified by age and are shown in Table I. Girls had an average higher WC, SBP, DBP and FBG than boys; however, the mean values of $\mathrm{BMI}, \mathrm{TG}$ and TC were higher in boys than in girls. Other than HDL and TC, in both genders, the BMI, WC, SBP, $\mathrm{DBP}$, and TG was raised significantly by increasing the age. There was no significant difference in mean FBG between age groups.

Overall, $423(8.1 \%)$ of our subjects were overweight and $477(9.2 \%)$ were obese. In the age group 10-13.9 years, $9.5 \%(\mathrm{n}=94)$ and $11.2 \%(\mathrm{n}=110)$ of boys were overweight and obese, respectively. In the 14-18 years boy category, $155(9.6 \%)$ and $166(10.3 \%)$ of participants were overweight and obese, respectively. In girls, 61 $(6.3 \%)$ and $80(8.3 \%)$ in the age group $10-13.9$ years were placed in overweight and obese groups, respectively. The percentages of overweight and obese subjects in the age group $14-18$ years were $6.9 \%(\mathrm{n}=113)$ and $7.4 \%$ $(\mathrm{n}=121)$, respectively.

Table II shows the mean values of cMetS in participants according to the number of MetS components. In total, $43.9 \%$ of the participants did not have any MetS components, whereas $4.4 \%$ had MetS. A graded relationship was documented between cMetS and the number of risk factors. Increasing the mean values of cMetS with increasing the numbers of components was apparent for both genders and in both age groups.

Table III presents the cut-off points of cMetS to predict the presence of MetS with their corresponding specificity and sensitivity by gender. In boys, cMetS values that maximised the sensitivity and specificity for MetS ranged from 2.34 in 10-13.9 years to 2.97 in $14-18$ years. The analogous values for girls ranged from 3.26 in 10-13.9 years to 2.47 in 14-18 years. The overall optimal cMetS cut-off point of MetS was 2.93 [sensitivity $=92 \%$, specificity $=$ $91 \%$, area of the curve $=0.96(0.95-0.97)$ ] (Fig. 1). As a whole, the values for boys and girls were 2.97 and 
Table I. Characteristics of participants according to gender and age groups

Tabela I. Charakterystyka uczestników badania w zależności od ptci i grupy wiekowej

\begin{tabular}{|c|c|c|c|}
\hline \multicolumn{4}{|c|}{ Age groups (years) } \\
\hline & $10-13.9$ & $14-18$ & Total \\
\hline \multicolumn{4}{|l|}{ Boys } \\
\hline$n$ & 638 & 1,041 & 1,679 \\
\hline Age (years) & $11.98 \pm 0.89$ & $16.04 \pm 1.41$ & $14.49 \pm 2.33^{b}$ \\
\hline $\mathrm{BMI}\left[\mathrm{kg} / \mathrm{m}^{2}\right]$ & $17.59 \pm 3.69$ & $20.71 \pm 3.90$ & $19.53 \pm 4.11^{\mathrm{b}}$ \\
\hline WC [cm] & $61.87 \pm 8.69$ & $69.82 \pm 9.40$ & $66.84 \pm 9.92^{b}$ \\
\hline SBP [mm Hg] & $97.08 \pm 13.64$ & $103.88 \pm 12.53$ & $101.25 \pm 13.39^{b}$ \\
\hline $\mathrm{DBP}[\mathrm{mm} \mathrm{Hg}]$ & $62.55 \pm 10.93$ & $66.06 \pm 10.05$ & $64.73 \pm 10.53^{b}$ \\
\hline FBG [mg/dL] & $86.65 \pm 11.78$ & $87.48 \pm 16.41$ & $87.10 \pm 14.83$ \\
\hline $\mathrm{TG}[\mathrm{mg} / \mathrm{dL}]$ & $92.10 \pm 41.67$ & $95.65 \pm 40.55$ & $94.32 \pm 41.0^{\mathrm{b}}$ \\
\hline $\mathrm{TC}[\mathrm{mg} / \mathrm{dL}]$ & $150.02 \pm 31.11$ & $151.19 \pm 31.65$ & $150.75 \pm 31.44$ \\
\hline HDL-C & $47.29 \pm 14.28$ & $45.29 \pm 14.02$ & $46.22 \pm 14.14^{b}$ \\
\hline \multicolumn{4}{|l|}{ Girls } \\
\hline $\mathrm{n}$ & 572 & 1,003 & 1,575 \\
\hline Age (years) & $12.12 \pm 0.82$ & $16.04 \pm 1.40$ & $14.60 \pm 2.25^{b}$ \\
\hline $\mathrm{BMI}\left[\mathrm{kg} / \mathrm{m}^{2}\right]$ & $17.59 \pm 3.63$ & $20.05 \pm 4.05$ & $19.14 \pm 4.10^{\mathrm{b}}$ \\
\hline$W C[\mathrm{~cm}]$ & $63.86 \pm 10.16$ & $72.40 \pm 11.08$ & $69.26 \pm 11.51^{b}$ \\
\hline SBP [mm Hg] & $100.97 \pm 13.08$ & $106.86 \pm 13.95$ & $104.71 \pm 13.93^{b}$ \\
\hline $\mathrm{DBP}[\mathrm{mm} \mathrm{Hg}]$ & $64.83 \pm 11.11$ & $67.92 \pm 11.01$ & $66.77 \pm 11.14^{b}$ \\
\hline FBG [mg/dL] & $80.23 \pm 12.74$ & $88.38 \pm 12.63$ & $88.33 \pm 12.67$ \\
\hline $\mathrm{TG}[\mathrm{mg} / \mathrm{dL}]$ & $86.46 \pm 39.77$ & $93.73 \pm 45.76$ & $91.06 \pm 43.79^{b}$ \\
\hline $\mathrm{TC}[\mathrm{mg} / \mathrm{dL}]$ & $154.84 \pm 31.39$ & $140.86 \pm 30.37$ & $146.03 \pm 31.48^{b}$ \\
\hline HDL-C & $48.52 \pm 15.58$ & $44.61 \pm 12.94$ & $46.05 \pm 14.09^{b}$ \\
\hline \multicolumn{4}{|l|}{ Total } \\
\hline$n$ & 1,210 & 2,044 & 3,254 \\
\hline Age (years) & $12.05 \pm 0.86^{\mathrm{a}}$ & $16.04 \pm 1.40$ & $14.55 \pm 2.29^{b}$ \\
\hline BMI $\left[\mathrm{kg} / \mathrm{m}^{2}\right]$ & $17.59 \pm 3.66$ & $20.38 \pm 4.00^{\mathrm{a}}$ & $19.33 \pm 4.10^{a, b}$ \\
\hline WC [cm] & $62.85 \pm 9.49^{\mathrm{a}}$ & $71.12 \pm 10.36^{a}$ & $68.05 \pm 10.81^{\mathrm{a}, \mathrm{b}}$ \\
\hline SBP [mm Hg] & $98.95 \pm 13.51^{\mathrm{a}}$ & $105.38 \pm 13.35^{\mathrm{a}}$ & $102.96 \pm 13.76^{\mathrm{a}, \mathrm{b}}$ \\
\hline $\mathrm{DBP}[\mathrm{mm} \mathrm{Hg}]$ & $63.67 \pm 11.08^{\mathrm{a}}$ & $66.98 \pm 10.57^{\mathrm{a}}$ & $65.74 \pm 10.88^{\mathrm{a}, \mathrm{b}}$ \\
\hline FBG [mg/dL] & $87.42 \pm 12.27^{a}$ & $87.92 \pm 14.67$ & $87.74 \pm 13.83^{a}$ \\
\hline TG [mg/dL] & $89.29 \pm 40.02^{\mathrm{a}}$ & $94.70 \pm 43.21$ & $92.71 \pm 42.42^{\mathrm{a}, \mathrm{b}}$ \\
\hline $\mathrm{TC}[\mathrm{mg} / \mathrm{dL}]$ & $152.37 \pm 31.32^{\mathrm{a}}$ & $146.07 \pm 31.44^{a}$ & $148.42 \pm 31.55^{\mathrm{a}, \mathrm{b}}$ \\
\hline HDL-C & $47.89 \pm 14.93$ & $45.10 \pm 13.50$ & $46.14 \pm 14.11^{b}$ \\
\hline
\end{tabular}

${ }^{a} \mathrm{p}<0.05$ between genders, ${ }^{\mathrm{b}} \mathrm{p}<0.05$ between age groups; BMI — body mass index; $\mathrm{WC}$ - waist circumference; SBP — systolic blood pressure; DBP — diastolic blood pressure; FBG — fasting blood glucose; TG v triglyceride; TC — total cholesterol; HDL-C — high density lipoprotein cholesterol

3.26 , respectively. The overall performance of the ROC curves for the estimated cMetS cut-off points were quantified by computing sex- and age-specific AUCs. In all groups, cMetS performed well $(0.9<$ AUC $\leq 1.0$; highly accurate) in classifying subjects to true MetS status (Fig. 2).

\section{Discussion}

This study confirmed the utility and validity of the cMetS score in a nationally representative sample of Iranian children and adolescents. cMetS appears to be an appropriate index for investigating the association 
Table II. Continuous Metabolic Syndrome score by numbers of MetS components

Tabela II. Ciagły wskaźnik zespołu metabolicznego w zależności od liczby komponentów

\begin{tabular}{|c|c|c|c|c|c|c|c|c|}
\hline \multirow{3}{*}{$\begin{array}{l}\text { MetS } \\
\text { components }\end{array}$} & \multicolumn{4}{|c|}{ Boys } & \multicolumn{4}{|c|}{ Girls } \\
\hline & \multicolumn{2}{|r|}{$10-13.9$ years } & \multicolumn{2}{|r|}{ 14-18 years } & \multicolumn{2}{|c|}{$10-13.9$ years } & \multicolumn{2}{|c|}{$14-18$ years } \\
\hline & $\mathbf{N}(\%)$ & $\begin{array}{l}\text { cMetS } \\
\text { score }\end{array}$ & $\mathbf{N}(\%)$ & $\begin{array}{l}\text { cMetS } \\
\text { score }\end{array}$ & $\mathbf{N}(\%)$ & $\begin{array}{l}\text { cMetS } \\
\text { score }\end{array}$ & $\mathbf{N}(\%)$ & $\begin{array}{l}\text { cMetS } \\
\text { score }\end{array}$ \\
\hline 0 & 333 (52.2) & $-1.17 \pm 1.83$ & $475(45.6)$ & $-1.45 \pm 1.81$ & $258(45.1)$ & $-1.60 \pm 1.72$ & $363(36.2)$ & $-1.89 \pm 1.85$ \\
\hline 1 & $218(34.2)$ & $0.44 \pm 1.78$ & $383(36.8)$ & $0.32 \pm 2.20$ & $237(41.4)$ & $0.07 \pm 1.89$ & $429(42.8)$ & $-0.02 \pm 1.75$ \\
\hline 2 & $71(11.1)$ & $3.06 \pm 2.05$ & $148(14.2)$ & $2.44 \pm 1.98$ & $64(11.2)$ & $3.09 \pm 2.18$ & $143(14.2)$ & $2.56 \pm 2.20$ \\
\hline+3 & $16(2.5)$ & $5.47 \pm 2.59$ & $35(3.4)$ & $4.72 \pm 2.12$ & $13(2.3)$ & $6.35 \pm 2.29$ & $68(6.8)$ & $5.47 \pm 2.30$ \\
\hline Total & 638 & $0.02 \pm 2.45$ & 1,041 & $-0.04 \pm 2.56$ & 572 & $-0.20 \pm 2.56$ & 1,003 & $0.04 \pm 2.80$ \\
\hline
\end{tabular}

Values are mean (SD) and \% where indicated; cMetS — continuous Metabolic Syndrome

Table III. Receiver operator curve for cMetS score for identifying children with MetS

Tabela III. Krzywa ROC dla wskaźnika cMetS w celu identyfikacji dzieci z zespołem metabolicznym

\begin{tabular}{lcccc}
\hline $\begin{array}{l}\text { Sex/Age value } \\
\text { Boys }\end{array}$ & cMetS score cut-off points & Sensitivity (\%) & Specificity (\%) & AUC (95\% CI) \\
\hline $10-13.9$ & 2.34 & & & \\
\hline $14-18$ & 2.97 & $94.0(91.9-95.7)$ & $87.0(84.1-89.5)$ & $0.96(0.93-0.99)$ \\
\hline Girls & & $94.0(92.3-95.3)$ & $91.0(89.0-92.6)$ & $0.94(0.91-0.98)$ \\
\hline $10-13.9$ & 3.26 & & & \\
\hline $14-18$ & 2.47 & $100.0(99.3-100)$ & $93.0(90.5-94.9)$ & $0.98(0.97-0.99)$ \\
\hline Sex-specific value & $94.0(92.2-95.3)$ & $88.0(85.9 \mathrm{v} 89.9)$ & $0.97(0.96-0.98)$ \\
\hline Boys & 2.97 & & & $0.95(0.92-0.97)$ \\
\hline Girls & 3.26 & $92.0(90.6-93.3)$ & $91.0(89.5-92.3)$ & $0.97(0.96-0.98)$ \\
\hline Overall value & 2.93 & $90.0(88.4-91.4)$ & $93.0(91.6-94.2)$ & $0.96(0.95-0.97)$ \\
\hline
\end{tabular}

cMetS — continuous Metabolic Syndrome; AUC — area under curve

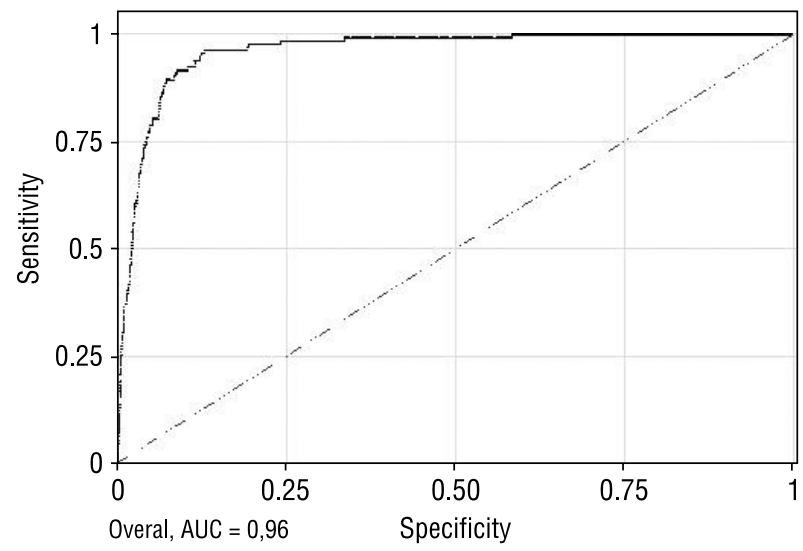

Figure 1. Overall ROC curve of cMetS risk score corresponding to Metabolic Syndrome. ROC - receiver operating characteristics; cMetS - continuous Metabolic Syndrome

Rycina 1. Ogólna krzywa ROC dla wartości wskaźnika cMetS odpowiadajacych zespotowi metabolicznemu

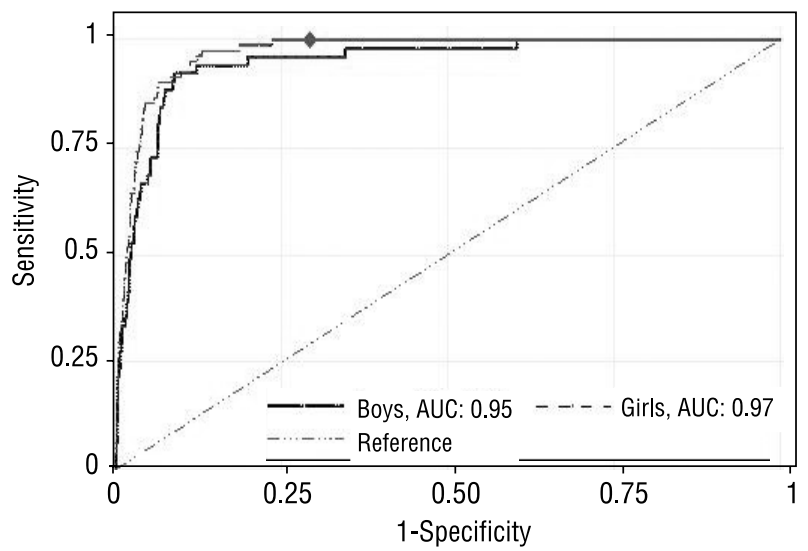

Figure 2. Sex-specific ROC curves of cMetS risk score corresponding to Metabolic Syndrome. ROC - receiver operating characteristics; cMetS - continuous Metabolic Syndrome

Rycina 2. Osobne dla obu ptci krzywe ROC dla wartości wskaźnika cMetS odpowiadających zespołowi metabolicznemu 
between potential risk factors and MetS in paediatric epidemiological research in our country.

MetS increases the risk of developing most chronic diseases, notably type 2 diabetes and cardiovascular diseases [29]. However, MetS is not limited to adults. There is a growing body of evidence about its presence from early childhood [30]. Changes in childhood lifestyle represent a significant concern in public health and paediatric medicine at both population and individual levels [31]. The prevalence of MetS in children and adolescents varies according to the definitions used for the components [32]. It must be emphasised that the lack of consensus in the definition may be responsible for varied findings across the epidemiologic studies [4]. Several studies have supported the use of continuous variables in a multivariate score system [11, 33]. cMetS is statistically more sensitive and less error-prone compared to the categorical approach. A study has demonstrated higher cMetS in Mexican-American children compared to white boys and girls [34].

To the best of our knowledge, this study is the first investigation that uses a nationally representative sample to validate the cMetS score in children in the Middle East and North Africa (MENA) region. Our findings documented a graded relationship between cMetS and the number of MetS components, i.e. having at least three MetS components is associated with the highest cMetS value. A rising mean value of cMetS with increasing the number of MetS components was observed in each age stratified gender. Furthermore, the overall optimal cMetS cut-off point which confers the risk of MetS was 2.93. A recent study by Okosun et al. [17] indicated that cMetS was a valid construct of MetS in children with a cut-off value of 1.94 . Likewise, Eisenmann et al. found that a cMetS of 3.72 considered as the optimal cut-off point confers an increased risk of MetS in a sample of 7-9 year-old children [18]. Since the MetS score is a sample specific, the mean MetS score derived in one survey cannot be compared to other studies unless variables and distribution of data are similar in the samples [33].

Although in our study, the results of the ROC analysis indicated different cut-off points of cMetS according to age and gender, cMetS was found to perform better in identifying MetS in both genders. In a previous national study, we showed that the prevalence of MetS in women was significantly higher than in men [35]. We suggest that the higher cut-off value of cMetS in women in our study compared to Western countries could be because of the underlying ethnic predispositions that contribute to insulin resistance and adverse body fat pattern in non-European populations [36]. Our findings highlighted an overall greater WC in girls than in boys.
Considering the high prevalence of abdominal obesity in Iranian females [37], the higher relative risk for incident MetS in this group could be justified. Furthermore, in all age groups we found a significant increase in mean TG values in boys. Consistent with several studies [17, 38], our findings suggest that central obesity and high TG have the most influence on MetS and cMetS score. Unhealthy diets, as well as the physical inactivity of Iranian children [39], could well be among the major contributors to the present and future health status of this group and are likely to confer an increased risk of chronic disease in adulthood [40]. These findings also confirm that the same set of adult criteria can be used in the calculation of the cMetS score and also highlights the importance of cMetS as a predictive utility on disease outcome [33, 41].

The validity of cMetS score in children has been examined in a few previous studies [17, 18, 42]. In our study, the construct validity of cMetS for MetS was high (AUC $\geq 0.94$; sensitivity $\geq 90 \%$ and specificity $\geq 87 \%$ ). In a study in children and adolescents $12-19$ years old, the cMetS, determined by principal components analysis, was significantly higher in those individuals with MetS as defined by the NHANES [17]. Our findings are consistent with this study and support the use of cMetS in epidemiological surveys.

Our findings should be interpreted while considering some limitations. The major limitation of this study and previous studies about cMetS is the specificity of sample. Therefore, a standardised method of calculating the score may prove beneficial in comparing studies. Another limitation is that we included WC, MAP, HDLC, TG, and FBG in calculation of cMetS. Some studies have used the markers of insulin resistance, instead of serum glucose levels, because blood glucose is usually in the normal range in youth [43]. We selected blood glucose levels because they were employed by ATP-III, and International Diabetes Federation adult clinical criteria for the definition of MetS [24, 26]. The other limitation was that we could not stratify according to maturation stage because of the limitations for the large number of study participants.

For the first time in Iran, and to the best of our knowledge in the Middle East and North Africa (MENA), we have assessed the construct and predictive validity of cMetS in a large nationally representative sample of children in order to find early identification of those who are at risk. This is also the first investigation to determine the age- and sex-specific cMetS cut-off points in Iranian children and adolescents. We noticed to age groups because of the strong association of age with maturity and the influence of growth and maturation on the development of the metabolic risk factors. 


\section{Conclusion}

This study shows that cMetS is an appropriate and valid index of MetS for paediatric epidemiological surveys. The use of cMetS enhances the role of potential risk factors in MetS. Further studies are needed to compare the ultimate net value of cMetS with the dichotomised definition of MetS. We also need a standardised and practical method of calculating the score to compare different populations, and then cMet $\mathrm{S}$ score could be used in clinical practice and public health to better understand the prevention and treatment of this emerging paediatric condition.

\section{Acknowledgment}

This nationwide survey was conducted in Iran with the co-operation of the Ministry of Health and Medical Education, the Ministry of Education and Training, the Child Health Promotion Research Centre at Isfahan University of Medical Sciences, and the Endocrinology and Metabolism Research Institute of Tehran University of Medical Sciences.

\section{References}

1. Reppert A, Steiner BF, Chapman-Novakofski K. Prevalence of metabolic syndrome and associated risk factors in Illinois. Am J Health Promot 2008; 23: 130-138.

2. Day C. Metabolic syndrome, or What you will: definitions and epidemiology. Diab Vasc Dis Res 2007; 4: 32-38.

3. Liu W, Lin R, Liu A et al. Prevalence and association between obesity and metabolic syndrome among Chinese elementary school children: a school-based survey. BMC Public Health 2010; 10: 780.

4. Nguyen NT, Magno CP, Lane KT et al. Association of hypertension, diabetes, dyslipidemia, and metabolic syndrome with obesity: findings from the National Health and Nutrition Examination Survey, 1999 to 2004. J Am Coll Surg 2008; 207: 928-934.

5. Kelishadi R, Ardalan G, Gheiratmand R et al. Paediatric metabolic syndrome and associated anthropometric indices: the CASPIAN Study. Acta Paediatr 2006; 95: 1625-1634.

6. Kahn R, Buse J, Ferrannini E et al. The metabolic syndrome: time for a critical appraisal: joint statement from the American Diabetes Association and the European Association for the Study of Diabetes. Diabetes Care 2005; 28: 2289-2304.

7. Tentolouris N, Papazafiropoulou A, Moyssakis I et al. Metabolic syndrome is not associated with reduction in aortic distensibility in subjects with type 2 diabetes mellitus. Cardiovasc Diabetol 2008; 7: 1 .

8. Eisenmann JC. Aerobic fitness, fatness and the metabolic syndrome in children and adolescents. Acta Paediatr 2007; 96: 1723-1729.

9. Ragland DR. Dichotomizing continuous outcome variables: dependence of the magnitude of association and statistical power on the cutpoint. Epidemiology 1992; 3: 434-440.

10. Klein BE, Klein R, Lee KE. Components of the metabolic syndrome and risk of cardiovascular disease and diabetes in Beaver Dam. Diabetes Care 2002; 25: 1790-1794.

11. WijndaeleK, Beunen G, Duvigneaud Netal. A continuous metabolic syndrome risk score: utility for epidemiological analyses. Diabetes Care 2006; 29: 2329.

12. Katzmarzyk PT, Perusse L, Malina RM et al. Stability of indicators of the metabolic syndrome from childhood and adolescence to young adulthood: the Quebec Family Study. J Clin Epidemiol 2001; 54: 190-195.

13. Andersen LB, Harro M, Sardinha LB et al. Physical activity and clustered cardiovascular risk in children: a cross-sectional study (The European Youth Heart Study). Lancet 2006; 368: 299-304.

14. Brage S, Wedderkopp N, Ekelund U et al. Features of the metabolic syndrome are associated with objectively measured physical activity and fitness in Danish children: the European Youth Heart Study (EYHS). Diabetes Care 2004; 27: 2141-2148.

15. Eisenmann JC, Katzmarzyk PT, Perusse L et al. Aerobic fitness, body mass index, and CVD risk factors among adolescents: the Quebec family study. Int J Obes (Lond) 2005; 29: 1077-1083.
16. Raitakari OT, Porkka KV, Rasanen $L$ et al. Clustering and six year clustertracking of serum total cholesterol, HDL-cholesterol and diastolic blood pressure in children and young adults. The Cardiovascular Risk in Young Finns Study. J Clin Epidemiol 1994; 47: 1085-1093.

17. Okosun IS, Lyn R, Davis-Smith M et al. Validity of a continuous metabolic risk score as an index for modeling metabolic syndrome in adolescents. Ann Epidemiol 2010; 20: 843-851.

18. Eisenmann JC, Laurson KR, DuBose KD et al. Construct validity of a continuous metabolic syndrome score in children. Diabetol Metab Syndr 2010; 2 : 8 .

19. Zimmet $\mathrm{P}$. The burden of type 2 diabetes: are we doing enough? Diabetes \& metabolism 2003; 29: 6S9-6S18.

20. Ghassemi H, Harrison G, Mohammad K. An accelerated nutrition transition in Iran. Public Health Nutr 2002; 5: 149-155.

21. Kelishadi R, Heshmat R, Motlagh ME et al. Methodology and Early Findings of the Third Survey of CASPIAN Study: A National SchoolBased Surveillance of Students' High Risk Behaviors. Int J Pre Med 2012; 3: 394-401.

22. McNamara JR, Schaefer EJ. Automated enzymatic standardized lipid analyses for plasma and lipoprotein fractions. Clin Chim Acta 1987; 166: 1-8.

23. Cook S, Weitzman M, Auinger P et al. Prevalence of a metabolic syndrome phenotype in adolescents: findings from the third National Health and Nutrition Examination Survey, 1988-1994. Arch Pediatr Adolesc Med 2003; 157: 821-827.

24. Antonopoulos S. Third report of the National Cholesterol Education Program (NCEP) expert panel on detection, evaluation, and treatment of high blood cholesterol in adults (Adult Treatment Panel III) final report. Circulation 2002; 106: 3421.

25. Genuth S, Alberti KG, Bennett P et al. Follow-up report on the diagnosis of diabetes mellitus. Diabetes Care 2003,26: 3160-3167.

26. Alberti KG, Zimmet P, Shaw J. The metabolic syndrome - a new worldwide definition. Lancet 2005; 366: 1059-1062.

27. Perkins NJ, Schisterman EF. The inconsistency of "optimal" cutpoints obtained using two criteria based on the receiver operating characteristic curve. Am J Epidemiol 2006; 163: 670-675.

28. Zweig MH, Campbell G. Receiver-operating characteristic (ROC) plots: a fundamental evaluation tool in clinical medicine. Clin Chem 1993; 39: 561-577.

29. Ford ES. Risks for all-cause mortality, cardiovascular disease, and diabetes associated with the metabolic syndrome: a summary of the evidence. Diabetes Care 2005; 28: 1769-1778.

30. de Ferranti SD, Gauvreau K, Ludwig DS et al. Prevalence of the metabolic syndrome in American adolescents: findings from the Third National Health and Nutrition Examination Survey. Circulation 2004; 110: 2494-2497.

31. Kelishadi R, Cook SR, Motlagh ME et al. Metabolically obese normal weight and phenotypically obese metabolically normal youths: the CASPIAN Study. J Am Diet Assoc 2008; 108: 82-90.

32. Boker S, Frelut ML, Vania A et al. Prevalence of matabolic syndrome in European obese children. Int J Pediatr Obes 2008, 1; 3 (Suppl. 2): 3-8.

33. Eisenmann JC. On the use of a continuous metabolic syndrome score in pediatric research. Cardiovascular diabetology 2008; 7: 17.

34. Batey LS, Goff DC, Jr., Tortolero SR et al. Summary measures of the insulin resistance syndrome are adverse among Mexican-American versus non-Hispanic white children: the Corpus Christi Child Heart Study. Circulation 1997; 96: 4319-4325.

35. Delavari A, Forouzanfar MH, Alikhani S et al. First nationwide study of the prevalence of the metabolic syndrome and optimal cutoff points of waist circumference in the Middle East: the national survey of risk factors for noncommunicable diseases of Iran. Diabetes Care 2009; 32: 1092-1097.

36. Dowse G, Zimmet P. The thrifty genotype in non-insulin dependent diabetes. BMJ 1993; 306: 532-533.

37. Zabetian A, Hadaegh F, Azizi F. Prevalence of metabolic syndrome in Iranian adult population, concordance between the IDF with the ATPIII and the WHO definitions. Diabetes Res Clin Pract 2007; 77: 251-257.

38. Smith SC Jr. Multiple risk factors for cardiovascular disease and diabetes mellitus. Am J Med 2007; 120: S3-S11.

39. Kelishadi R, Ardalan G, Gheiratmand R et al. Association of physical activity and dietary behaviours in relation to the body mass index in a national sample of Iranian children and adolescents: CASPIAN Study. Bull World Health Organ 2007; 85: 19-26.

40. Morrison JA, Friedman LA, Wang P et al. Metabolic syndrome in childhood predicts adult metabolic syndrome and type 2 diabetes mellitus 25 to 30 years later. J Pediatr 2008; 152: 201-206.

41. Cruz ML, Goran MI. The metabolic syndrome in children and adolescents. Curr Diab Rep 2004; 4: 53-62.

42. Pandit D, Chiplonkar S, Khadilkar A et al. Efficacy of a continuous metabolic syndrome score in Indian children for detecting subclinical atherosclerotic risk. Int J Obes (Lond) 2011; 35: 1318-1324.

43. Gungor N, Saad R, Janosky J et al. Validation of surrogate estimates of insulin sensitivity and insulin secretion in children and adolescents. J Pediatr 2004; 144: 47-55. 